\title{
The gendered embodiment of shame: Intersections of acquaintance rape, trauma and self-blame in Pompidou posse by Sarah Lotz
}

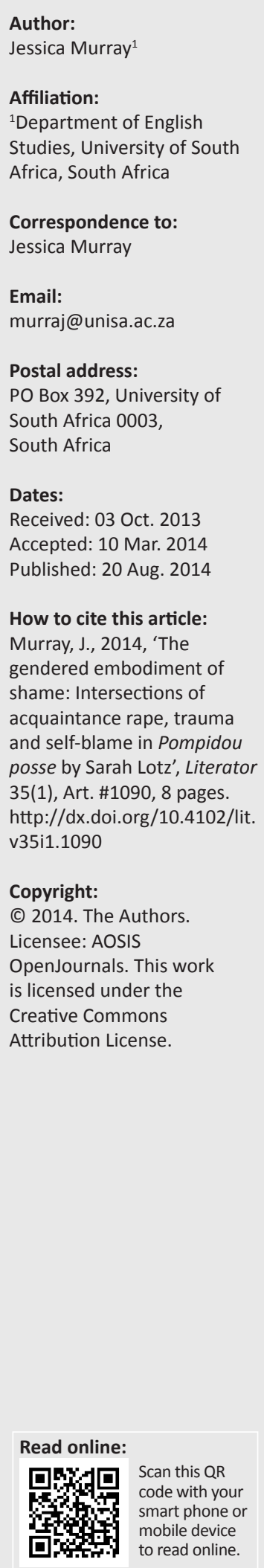

This article offers a feminist literary analysis of the gendered embodiment of shame in Pompidou posse by Sarah Lotz. In this novel, Lotz depicts female characters who are sexually assaulted by acquaintances and the resultant shame and trauma reside in their bodies. I will demonstrate that the embodied shame of these characters is distinctly gendered and that this shapes their attempts to cope with the aftermath of the sexual assaults. A close reading of the text reveals that the characters are exposed to overwhelming social messages of female culpability in a larger context that is rife with misogyny. As a result, they anticipate blame to such an extent that they blame themselves and internalise this blame as shame. By focusing on the bodies of the survivors, Lotz demonstrates the embodiment of shame, but she also suggests a corporeal challenge to silencing. The bodies of these characters speak loudly, albeit sometimes in the halting language of trauma, and they function to alert them to danger, to help them excavate memories that are made inaccessible and to testify to traumatic sexual assault.

Die genderdiskoers oor die beliggaming van skaamte: Snypunte van verkragting deur kennisse, trauma en selfblaam in Sarah Lotz se Pompidou posse. Hierdie artikel bied 'n feministiese letterkundige ontleding van die genderdiskoers oor die beliggaming van skaamte in Sarah Lotz se Pompidou posse. In hierdie roman stel Lotz vroulike karakters voor wat seksueel aangerand word deur kennisse en die gepaardgaande skaamte wat in hulle liggame gehuisves word. Ek sal illustreer dat die liggaamlike skaamte van die karakters geslagsrolbepaald is en dat dit hul pogings om die gevolge van die aanrandings te verwerk, beïnvloed. 'n Narratiewe lesing van die teks onthul dat die karakters blootgestel word aan oorweldigende sosiale boodskappe van vroue se laakbaarheid in 'n breër konteks waarbinne vrouehaat algemeen is. Die gevolg is dat vroue blaam tot so 'n mate verwag, dat hulle hulself blameer en die blaam internaliseer as skaamte. Deur te fokus op die liggame van hierdie vroulike karakters demonstreer Lotz die beliggaming van skaamte, maar stel sy ook liggaamlike uitdagings aan stilswye. Die liggame van die karakters praat luidkeels, al is dit soms in die huiwerige taal van trauma. Hulle liggame waarsku hulle wanneer daar gevaar is, help hulle om herinneringe te ontgin wat ontoeganklik is en bied 'n manier om te getuig oor traumatiese seksuele aanrandings.

\section{Introduction}

A great deal of research suggests that acquaintance rapes are the most likely to be trivialised because society and legal systems remain loathe to see this 'victimization as real rape' (Estrich 1992:137). Sue Lees (2002) explains that:

women raped by acquaintances found the experience even more difficult to come to terms with than those raped by strangers. They felt betrayed - not just by the men, but by their own judgment. (p. 17)

Richard Felson and Paul-Philippe Paré (2005:598) find that 'sexual assaults involving nonstrangers are particularly unlikely to be reported', not least because the victims are more prone to blame themselves. Maria Vidal and Jenny Petrak's (2007:168) research reveals 'that women who knew the assailant felt more ashamed of themselves and their bodies following the sexual assault than if the assailant was a stranger'. Sara Ahmed (2004:148) describes shame as 'an intense and painful sensation that is bound up with how the self feels about itself, a self-feeling that is felt by and on the body'. According to Sinéad McDermott (2011:145), the 'association of shame with bodily vulnerability, exposure and potential disintegration of the self, all suggest a strong connection between shame and trauma'. Yet, McDermott (2011:145) notes that, whilst trauma studies and shame studies both constitute rich fields of scholarship, they 'have tended not to overlap'. This article will draw on trauma and shame studies, as well as sociological research on rape, in order to offer a feminist literary analysis of the gendered embodiment of shame in Pompidou posse (2008) 
by Sarah Lotz. In this novel, Lotz depicts female characters who are sexually assaulted by acquaintances and whose resultant shame and trauma reside in their bodies. I will demonstrate that the embodied shame of these characters is distinctly gendered and that this shapes their attempts to cope with the aftermath of the sexual assaults. The novel represents important social issues and, by harnessing the interdisciplinary insights from various fields of research, the article seeks to provide a richer understanding of the experiences of these literary characters.

\section{Shame, gender and alcohol consumption}

In the novel, Lotz (2008) explores the shame that results when a female character is unable to remember the details of sexual assault because of alcohol-induced blackouts. A significant body of research confirms that 'alcohol appears to play an exacerbating role in the assignment of blame to the victim of an acquaintance rape' and that the 'more drunk the victim is, the greater the degree of responsibility and blame that is assigned to her' (Cameron \& Stritzke 2003:985). Being blamed for one's own victimisation leads to shamed stigmatisation, which makes it much less likely that a survivor will report a rape. Lotz's novel constitutes an imaginative space in which the author and readers can explore and confront the gendered implications of women's experiences that are all too often silenced. A number of scenes reveal Lotz's engagement with gendered representations of shame, the inscription of trauma on the bodies of female characters and their sexual vulnerability. In Pompidou posse the plot revolves around the experiences of two teenage British girls, Vicki and Sage, who have run away from home and find themselves living on the streets of Paris. After an evening out, Vicki wakes up naked in a room she does not recognise. She has no recollection of how she got there and the first thing she asks herself is 'What was I drinking last night?' (p. 45). When she cannot remember enough to answer this question, she employs the following strategy: 'I make myself burp, and taste the familiar chemical after-effects of too much whisky' (p. 45). By turning to her body's memories, she finds that certain segments of the past are 'not known in words, but in the body' (Culbertson 1995:170). After surveying the room without seeing any signs of her clothes, she starts 'to feel a bit panicky' and she wonders: 'How can I not remember any of this?' (p. 46). Despite the fact that she cannot remember, her body bears some telltale signs of violence. There is 'a huge purple and yellow bruise about the size of a fist on the back of [her] thigh' and she has no idea how she got it. When she finally locates her clothes and puts on her dress, she notices 'that there's a large tear under one of the arms' (p. 48). Vicki is immediately concerned that she and a man she had been out with the previous evening had sex. Even though she has no recollection of the event, she does not refer to this possibility as rape, but wonders: 'Did we do it?' (p. 48). Given the blackout, the only way to answer this is to consult her body. She concludes: 'It doesn't feel like it - I don't feel sore or ... used' (p. 48). Even though Vicki could have been bruised in a drunken fall, and although she does not use the term rape, Lotz's terminological choices do prompt the reader to regard Vicki as a female character who had been vulnerable to violence. The bruise size is compared to a fist and sexual intercourse is associated with soreness and feeling used.

She tries to 'piece together' the previous night but she finds that 'it's like trying to remember someone else's life, or a scene from a crap movie or something' (p. 48). The depiction of Vicki's sense that she is looking at someone else's life suggests that she is experiencing the dissociation that often results from traumatic events. According to Bessel van der Kolk, James Hopper and Janet Osterman (2001):

memories of trauma, or at least of certain forms of trauma, are encoded by processes, such as repression and dissociation, that make them difficult to retrieve as coherent verbal narratives. The result is that traumatic memories are primarily available as isolated, nonverbal, sensory, motor, and emotional fragments. (p. 13)

The reference to a movie further implies that she has not integrated these memories into her own reality. This is also typical of traumatic memories which, according to Culbertson (1995), tend to:

take on a cast of unreality; however deeply known, they are also disbelieved, seem unbelievable, even to the survivor who knows quite well the truth, in his body if not in words. (p. 171)

Dori Laub (1992:57) notes that 'trauma precludes its registration; the observing and recording mechanisms of the human mind are temporarily knocked out, malfunction' whilst Jane Kilby (2002:205) contends that, due to the inaccessibility of a traumatic event, 'in a sense, therefore, there is nothing to remember except perhaps a sense that there might be something to remember'. Although the memories of the previous night prove to be elusive, Vicki clearly has a sense that something is lurking in her consciousness and that she needs to excavate it. She starts remembering snippets and, the more she recalls, the clearer it becomes that she had been sexually assaulted whilst intoxicated. Lotz makes repeated references to Vicki's awareness of her body as, even after trying to wash herself, she 'can still smell [her] body' (p. 48), she finds herself 'shivering uncontrollably' (p. 48), the 'skin over [her] entire body is covered with goose pimples' (p. 45) and she realises that she is 'still shaking' after getting dressed. Although some of these corporeal manifestations can be attributed to simply being cold, they are also reminiscent of Thomas Fuchs's (2004:7) argument that 'painful experiences are taken up into the memory of the body' and that the 'most indelible impression in body memory is caused by trauma'.

The previous evening whilst they were still in a restaurant, she and the two men she was with, Jules and Bobby, 'had got through at least three carafes of wine (or was it four?)' (p. 48). Although she remembers some things, there is little clarity, as suggested by her equivocation: 'We'd had coffee - I think' (p. 48). She and Jules then went back to his apartment. As Vicki's memories start to become clearer, it is increasingly apparent that Jules scripted this scenario with the explicit 
intent of sexually assaulting her. When they arrived in his apartment, Jules:

sat down on the green armchair and opened the bottle of whiskey. I think at first I'd sat at his feet. I'd had no choice. There's only one chair in the room. (p. 48)

Lotz (2008) represents her next recollections as follows:

Jules started stroking my head, gently at first, then harder, his fingers tangling painfully in my dreadlocks, and then I realised he was trying to push my head down into his lap. I remember thinking, 'when the fuck had he taken his kit off?' I hadn't even noticed he was sitting there half naked until it was too late. (p. 49)

In the scenario above, Vicki had not realised that she was at risk of sexual assault 'until it was too late'. She recalls: 'I'd felt it being forced down the back of my throat, and, unable to help it, I'd retched and almost choked' (p. 49, emphasis added). Vicki's reluctance to label this 'rape', even as she remembers a penis being 'forced' down her throat, bears out research that has:

consistently found that a large percentage of women - typically over $50 \%$ - who have experienced vaginal, oral, or anal intercourse against their will label their experience as something other than rape. (Kahn et al. 2003:233)

As this character's 'eyes were streaming with tears from [her] choking fit' and the 'room was whirling', she hears Jules laughing as he tells her 'stay down there, you can't start something and not finish it' (p. 49). Although she 'tried to lurch to her feet' in an apparent effort to get away from Jules, when he asks her whether she is 'okay', she recalls the following response: 'I think I said something like, "sure"' (p. 49). In her research into young people's negotiation of sexual consent, Anastasia Powell (2008:173) finds that young women often continue to accept the myth that they are responsible for men's sexuality, which once aroused cannot be stopped' and that they fail to 'refuse unwanted sex because they feel that it would be inappropriate' to do so. Jules's insistence that she should finish what she started echoes this gendered understanding of 'proper' feminine and masculine sexual behaviour. When these memories surface, Vicki's body again speaks loudly as she 'barely make[s] it to the tiny sink and spew[s] yellowish vomit over the dirty plates'. At this stage Lotz suggests that Vicki again reverts to a common strategy for dealing with traumatic memories when she tries to repress the recollections: 'Shit. Don't think about it' (p. 49). Brenda Shapiro and Conrad Schwarz (1997:416) identify 'dissociative-like experiences, intrusive experiences, and avoidance' as examples of trauma symptoms.

As these memories start returning, the question that preoccupies this character is: "Had I tried to say "non" or something? Had I?' Even though she remembers the tears, the pain, the retching and feeling forced, she identifies 'saying no' as the salient factor in determining whether this was sexual assault. Her focus on whether she articulated the word 'no' is hardly surprising. According to Powell (2008):

this is reflected in many rape prevention initiatives, in which young women are encouraged to "say no" clearly ... or to unambiguously communicate their intentions to a potential sexual aggressor. (p. 170)
There is, however, a great deal of ambiguity in the representation of this particular assault. The fact that Vicki cannot remember whether she said 'no' suggests that her ability to give consent was severely compromised. Yet, she told Jules that she was okay when he asked her and she 'remember[s] clearly following him up flights of stairs' to the apartment where the assault took place. Vicki is thus vulnerable to attributions of blame for a number of reasons, including 'following' a man she barely knew into his apartment, drinking too much and failing to communicate her refusal in unambiguous language, despite the clear articulations of her body. Sharon Cowan (2008) makes the following points in this regard:

Questions of capacity to consent to sexual intercourse are subject to ongoing prejudicial beliefs about appropriate gendered behavior, and ultimately, the underlying tenacious notion that a woman assumes the risk of any harm of sexual assault, and thus bears responsibility for any attack perpetrated upon her, particularly where she had been drinking. (p. 9)

Vicki's confusion results in a telling attempt to re-establish normative feminine behaviour. When she asks herself 'What now?', she comes to the following startling decision:

I'd better sort out the bedroom before he [Jules] gets back. Put the sheet back, put the eiderdown in place. ... I pull the duvet back into place. It doesn't look perfect but at least I've tried. (p. 49)

The intricate entanglement of women's sense of shame, sexual assault and alcohol consumption emerges most clearly in the section where Vicki sees Jules again. He offers her coffee and she responds politely by saying 'No thanks, Jules' but her body again alerts the reader to her profound discomfort as she finds that her 'voice sounds rusty, unused'. She then thinks:

I want to ask him how I ended up in his bed, alone - was I? last night. Had I taken my clothes off? Did he do that? I don't want him to think I'm some sort of fucked-up alcoholic though, someone who doesn't know what they're doing. So I just leave. (p. 50)

The unasked questions and the 'unused voice' suggest the silencing that all too often results in cases of sexual assault. All Vicki is able to manage is to revert to a very traditional 'feminine' script of polite suffering in silence. She cannot seem to help herself and when Jules asks her whether she slept well, she answers: "'Oui, merci". It's automatic' (p. 50). The shame of drinking so much that she could not remember, combined with the knowledge that she had put herself at risk and had perhaps not articulated the word 'no', causes her to walk away in shamed silence after tidying her attacker's bedroom and thanking him for the evening.

Charlene Lam and Brenda Roman (2009:23) confirm that, when women have been sexually assaulted by an acquaintance, they are 'unlikely to report their perpetrator to the police or tell anyone at all' because the victim often 'blames herself for the incident, is ashamed of the event, and fears judgment from others'. Lotz (2008) represents the potency of these social forces when Vicki does not even 
consider telling her closest friend, Sage, after she arrives back at their apartment. When Sage asks her where she has been all night and tells her that she 'was dead worried', Vicki admits that she was 'at Jules's' (p. 52). Vicki downplays the lack of control she had over the evening's events as follows: "'Sorry", I say. "It wasn't planned or anything. I kind of ... forgot the time"' (p. 52). At this stage the reader has the sense that things were indeed planned, albeit by Jules, and the ellipses suggest that Vicki is searching for a euphemism to cover up the fact that she had a blackout. Even more disconcerting is her response when Sage asks her whether she had fun: 'Yeah. It was alright' (p. 52).

In the aftermath of Vicki's sexual assault, Lotz (2008) represents a further controversial factor that adds to the ambiguity of reading Vicki's experience. Katherine Baker (1999:690) notes that, in the case of sexual assault by an acquaintance, 'many women continue to maintain a dating relationship with the man after the rape' with an American study suggesting that as many as $39 \%$ of victims may do so (Baker 1999:690). Lam and Roman (2009) explain the complex dynamics involved in this relatively unexplored phenomenon as follows:

Victims may feel that repeated sexual contact or beginning a relationship with the perpetrator alters the initial incident into a mutual decision. Continued sexual contact with the assailant may also indicate the victim's desire to regain control of her sex life and eliminate those images of the sexual assault. (p. 24)

When Vicki tells Sage that she is going out, Sage knows that she is going to be meeting Jules again. Even though Vicki has not told her friend what happened, their conversation is as follows: 'in a different, softer, unSage-like tone of voice she said "You don't have to go, you know". "What do you mean?" "To meet that bastard, tonight"' (p. 62). Vicki's response reveals her confusion, shame and the undeniable pull back into the mode of the polite feminine norm: 'I've said I would, now, Sage. It would be ... rude not to' (p. 62). Patricia Rozee and Mary Koss (2001:299) identify the 'socialization "to be nice" and put others' needs before our own' as factors that exacerbate women's vulnerability to sexual assault. The ellipses before the explanation that she is going to avoid appearing 'rude' again reveal a character that has not made sense of her reactions in her own mind yet.

Whilst her conscious mind has not processed her experiences, her body is sending her a number of fairly unambiguous signals that suggest anxiety and fear. As she is waiting for Jules to arrive at their designated meeting place, she notes: 'Now I'm getting really nervous, and butterflies flitter crazily in my stomach. I feel like I do just before an exam. ... My stomach flips when I see him, but I try to ignore it' (pp. 64-65, emphasis added). The events that transpire during the rest of the evening demonstrate that Vicki ignores these corporeal warnings at her peril. Jules has once again scripted a plot that involves using alcohol to lure Vicki into a space where she can be sexually victimised. Jules tells her that they are going to a bar where they will meet a friend of his: 'Just a friend, you will see. I think you will like her' (p. 65). After meeting the Japanese 'friend', Vicki 'forgot her name instantly' but she 'put[s] this down to the fact that [she has] been downing countless shot glasses of pastis' (p. 66). It is apparent that Jules is also plying the unnamed 'friend' with alcohol. Vicki notices that her 'voice sounds slurry' and that she is 'either off her head on drugs or she's completely cooked. Or both' (p. 67). When she 'holds up her empty glass and waves it above her head', 'Jules motions to the bartender again'. By the time the three of them are back in Jules's apartment, Vicki feels as if the 'room's spinning' and she realises that she has 'drunk too much and things start to spiral out of control' (p. 68). She attempts to re-establish a modicum of control by grounding herself in her body:

I bite the inside of my cheek hard. It feels numb, but this is an old trick I use to try and sober up.... I bite harder, and this time I can feel the reassuring salty irony taste of blood in my mouth, and the room steadies slightly. (p. 68)

By allowing her body to anchor her in the situation, Vicki is better able to assess the danger of sexual assault. In this representation, it seems as it 'the body [is] retaining its authority to remind the conscious brain of the body's role in warning the self of danger' (Jolly 2011:313). At first she simply tries to 'move away slightly' (p. 69). As is becomes apparent that Jules has orchestrated a threesome, Vicki's internal thought processes are clear: 'I don't want to be here, doing this' (p. 69).

Unlike with the previous assault when Vicki could not get away before it was too late, she is now much more aware of the danger, and her corporeal alarm system plays a crucial part in protecting her: 'My stomach lurches again. Get out of here now! Right this fucking second. Before it's too late' (p. 70). Although she now realises that she has to get away, she is struggling to control her body's actions. In the space of two pages, she reflects in panic: 'I manage to get up to my haunches, but my body doesn't want to do what I'm telling it to' (p. 70) and 'my body doesn't seem to want to listen to what I'm telling it to do' (p. 71). After she makes it out of the apartment and is trying to flee the building, she finds that her 'legs feel like heavy weights are strapped to them' (p. 71). The tendency to revert to self-blame is again apparent as she scolds herself 'Stupid, stupid, stupid!' (p. 71). She spends the night hiding in a cramped space in his apartment building with her body manifesting her fear as she is 'shaking like a spastic and [her] teeth are chattering' (p. 72). When she wakes up, the sense of corporeal heaviness is again apparent as her 'whole body feels as if it's made out of stone, or as if it's been coated in plaster of Paris' (p. 73). After she has finally managed to exit the building, she gratefully reflects: 'At least my body's listening to me now' (p. 74).

In a number of different scenes in the novel, Lotz (2008) represents how Vicki's experience of her own body, and the messages that, as a female body, it is necessarily shameful and vulnerable, shape her thoughts and actions. The decisions that place her at risk of sexual assault cannot be read in isolation. Rather, they crystallise in a context where misogyny is rife. Susan Bartky (1990:85) identifies in women 
'a pervasive sense of personal inadequacy that, like the shame of embodiment, is profoundly disempowering; both reveal the "generalized condition of dishonour" which is women's lot in sexist society'. In her analysis of J.M. Coetzee's Disgrace, Camille Nurka (2012:323) argues that the text establishes 'an irrevocable connection between rape, shame and the female body'. In Pompidou posse, the reader can discern a comparable thread linking sexual assault, shame and the bodies of female characters. Kat Banyard (2010) advocates that:

we need to put an end to the illusions that surround violence against women and recognize it for what it is: the inevitable consequence of a society riddled with sexism. (p. 135)

\section{She explains this further with the following instruction:}

Look beneath the surface and you find the roots of all these individual acts [of gender violence] connected in a tangle of gender inequality that is planted firmly in the heart of normal, everyday society - in behaviours deemed "manly", in cultures deemed "traditional. (Banyard 2010:107)

A close reading of Vicki's experiences does, indeed, reveal that the actual instances of sexual assault, or attempted assault, are anything but aberrations. In her normal, everyday life, she is confronted by sexism and misogyny in myriad ways. Before Vicki leaves to meet Jules the second time, she runs into a neighbour she has not met before. After 'cheerily' (p. 60) greeting him, she is unable to hear his response and the following exchange occurs:
'Pardon?' I said, turning round and politely smiling in his direction.
'Putain!' he hissed. The tone of his voice was pure poison and, as he spat out the word, I caught a glimpse of dark brown teeth beneath the snarl of his top lip.
'You what?' I said.
'Putain!' he hissed again; this time pointing at me, in case I was under any illusion that he meant someone else, even though the corridor was deserted as usual. (p. 60)

Although Vicki does not know what the French word means, she can tell that it 'didn't sound very nice' (p. 61). The old man's hostility is, however, unmistakable and, when Vicki learns that the word means 'whore', it is clear that he was pointing the finger of sexual shame at her. Even before she knows the translation, her response to this verbal attack is telling: "“Fuck you!" I shouted, but it sounded pathetic, defeated somehow' (p. 61). The description of Vicki's resistance as 'pathetic' and 'defeated' suggests the overwhelming nature of the misogyny to which Vicki is exposed.

It is just after this incident that Vicki leaves to meet Jules for the second time. Erika Carr and Dawn Szymanski (2011:40) argue that a focus on the dynamics of sexual objectification 'provides an important perspective for understanding the experiences of women living in a culture that sexualizes the female body'. They go on to explain that women are exposed to a continuum of sexual objectification that:

occurs in numerous ways such as practices of some men checking out a woman's 'goods', whistles or cat calls, sexual comments about women's body parts ... unwanted sexual advances, sexual harassment, and sexual assault. (Carr \& Szymanski 2011:40)
Whilst Vicki is waiting for Jules, she experiences yet another form of sexual objectification. She sees a limousine and, as 'it passes the back window slides down and a dark-skinned Italian-looking man pokes his head out and wolf-whistles' (p. 64). Vicki 'ignore[s] him and look[s] down at the pavement'. Vicki's aversion of her gaze to the ground can be read as a manifestation of shame which, according to Janice Irvine (2009:70), is 'mapped on the body in the blush, the averted eyes, the turning away'. Ahmed (2004) explains that shame:

feels like an exposure - another sees what I have done that is bad and hence shameful - but it also involves an attempt to hide, a hiding that requires the subject to turn away from the other. (p. 103)

The 'bad' and 'shameful' action that Vicki is guilty of, the text suggests, is being in a misogynist society in a female body. Laura Bauer (2011:366) notes that 'shame can be a crippling emotion and for women, experiencing shame in some form or another seems to be inescapable'. In her tellingly titled text Embodied shame: Uncovering female shame in contemporary women's writings, Brooks Bouson (2009:1) argues that 'to be made of female flesh is to be well-schooled in the abjections and humiliations of embodiment'. After finally making it out of Jules's apartment building, Vicki is again subjected to social messages of corporeal shame. As she walks by a 'bunch of scruffy looking tramps', one greets her 'knowingly and lasciviously' (p. 76). Her physical reaction again demonstrates her attempt to deal with this shameful exposure by hiding and turning away: 'I stalk past them, head down and hurriedly cross the road' (p. 76). Lest one forgets that the sense of threat and forces of shaming are gendered male in the novel, the reader learns that Vicki is 'almost overcome with relief as [she sees] the comforting female shapes of the sculptures that surround the opera house' (p. 76, emphasis added).

The extent to which 'self-blame is culturally inculcated in victims' (Lebowitz \& Roth 1994:365) emerges in Vicki's reflections about an incident that follows shortly after the second visit to Jules's apartment. An acquaintance, Bobby, tricked Vicki into working at a sex shop. From their first encounters, Bobby appears to regard Vicki's body as fair game and, in another example of feminine politeness in sexual scripts, she tends to ignore his advances to avoid causing him offence. Early in the novel, their interactions are described as follows: 'As he kisses me goodbye, Bobby squeezes my waist. I pretend not to notice' (pp. 29-30). When 'Bobby steered [her] into the horrible sex-shop' Vicki 'thought he was joking' because 'Bobby was supposed to be [her] friend' ( $\mathrm{p}$. 88). The text is once again drawing the reader's attention to an important shift in contemporary understandings of sexual assault and sexual threat. Amy Chasteen (2001) explains this shift as follows:

The notion of the rapist as a rare, fringe character was also reconstructed in feminist discourse. Prior to the feminist movement, the image of the stranger rapist in the proverbial dark alley was commonplace; feminists argued that this mythology hid the reality that the vast majority of assaults are by acquaintances or someone else the woman knows, such as her 
date or boyfriend. These are not unknown assailants, but often men that women think they can trust. (p. 106)

Vicki trusted Bobby and regarded him as a friend and these factors enabled him to lure her into a space where she was vulnerable to sexual victimisation. Vicki, however, takes the bulk of the blame on herself because, when she 'realized what was happening [she] should have put an end to it' (p. 88). She tells herself that she:

shouldn't have stood mutely behind the counter like a stuffed toy while the vile guy showed [her] how to use the till, his hand snaking around [her] waist and down [her] bum. (p. 88)

In addition, that she 'hadn't needed to get changed in front of him and Bobby' and that she 'didn't need to just sit there, behind that stinking counter, while that putrid old man wanked in front of the magazine stand' (p. 88). Yet, she did all these things. A number of factors can help account for Vicki's failure to resist these incidents of sexual victimisation. Chasteen (2001:107) notes that 'people learn scripts of male sexual aggression and female passivity' and that these acquired behaviour patterns 'encourage sexual assault of women'. The comparison to a 'stuffed toy' also suggests just how comprehensively Vicki has been objectified, which facilitates a situation in which she is 'treated as an object to be valued for its use by others'. In this case, Lotz (2008:88) makes the link between self-blame, shame, sexual victimisation and the body explicit: 'Hot shameful tears spring up from where they've been lurking traitorously for an opportunity to reappear. I grit my teeth and scowl as hard as I can'.. Vicki regards the 'shameful tears' as a betrayal by her body and she attempts to reign in this 'traitorous' corporeal manifestation of her pain by gritting her teeth and scowling.

Although most of the incidents of sexual objectification and sexual assault in the novel focus on Vicki's experiences, it emerges that Sage is not immune to sexual victimisation and the resultant shame that manifests on the female body. Towards the end of the narrative, Vicki sees her best friend undressed for the first time and what she sees is so shocking that she has 'to bite [her] tongue not to say anything':

There are criss-crossing white scars all along the inside of her forearms.... Some of the scars are thick and swollen like white bumpy earthworms, and I can trace them up to her elbows. Whatever caused them must have cut quite deep. (p. 324)

The exposure of these corporeal traces of the shame of sexual assault causes Sage to try to hide as 'she crosses her arms across her chest'. Even more unusual for the typically brash and loud-mouthed Sage, when she speaks again, Vicki notices 'her voice sounding small and lost' (p. 324). Although they are best friends, Vicki finds herself unable to ask Sage about 'the lacerations on her forearms'. As someone who is familiar with the shame of exposure, Vicki attempts to alleviate Sage's discomfort by mirroring the gestures of the shamed individual: 'I drop my eyes as fast as I can so that she can't see me staring' (p. 324, emphasis added).

It is only in the last 20 pages of the novel that Vicki broaches the subject and the connection between Sage's embodied shame, trauma and sexual assault by an acquaintance is made explicit. According to Sue McAndrew and Tony Warne (2005:172), 'deliberate self-harm [of which self-mutilation is an example] is an expression of extreme distress' and it is 'predominantly a female behaviour'. They argue that, in order to understand the complex phenomenon of selfharm, we need to consider traumatic past experiences, the 'gendered nature' of those experiences and, crucially, the fact of 'many women's experiences being set in a context of a predominantly patriarchal ordered society, which promotes an unequal distribution of power, often leaving women feeling powerless' (McAndrew \& Warne 2005:178). Sage admits that her traumatic childhood experience has been shrouded in silence and secrecy and she still appears to anticipate a negative response when she finally starts telling her story: 'When I was twelve. ... Look, Vicks, I haven't told anyone about this, so don't freak out, okay?' (p. 337). This is a conversation that can finally take place because it was initiated by Sage's body, which revealed the telltale signs of embodied shame to her friend. The ellipses indicate the halting and stumbling that typically characterise the language of trauma for, as Elaine Scarry (1985:172) has convincingly argued, 'pain actively destroys language'.

Sage explains that she was walking her dog in a wooded area in her childhood neighbourhood when she 'bumped into this guy, a friend of [her] sister Karen' (p. 338). During an earlier encounter at her sister's wedding, this man, who was 'much older' than Sage, had already expressed interest in her, which she had found unwelcome even then. She recalls: 'this guy'd asked me to dance with him at their shite wedding. I hadn't wanted to' (p. 338). When she runs into him in the isolated space of the woods and he makes conversation, she initially reads his interest as unthreatening:

So this guy's like, 'How are you?' etc., and at first I thought he was just being friendly. And he goes, 'Do you feel like walking with me for a bit?' (p. 339)

At this stage of sharing the narrative with Vicki, Sage 'pauses to relight the tiny stub of the joint, The words come out in a matter-of-fact, detached voice. A dead voice' (p. 339). The sense of detachment is another common phenomenon in stories of rape trauma. Winkler (1994:250) identifies a 'shattering feeling' that results from rape trauma, which can cause the body to feel like an object that is 'in some ways separate from the mind'. In her research into the articulation of violent experiences, Kali Tal (1996:122) finds that survivors often describe how words seem 'inadequate, worn, foolish, lifeless' when they attempt to harness language to recount their traumatic memories. In a lifeless voice, Sage recalls her increasing discomfort and her futile efforts to get away from this man:

So we walk a bit deeper into the woods and he tries to hold my hand, but I'm trying not to let him grab it. But I'm feeling like, really weird not, you know? As if something's not quite right, but I couldn't put my finger on what it was. And I was like, 'I have to get home now', and I'm pulling Cassie [her dog] away so we can scarper when he grabbed me and said something like, 'You know you want to, I've seen you looking at me', or something shite like that. (p. 339) 
The rapist is employing the common rape myths which hold that women are complicit in their own sexual assaults because they somehow 'asked for it', that they really wanted it, and that 'no means yes' (Bourke 2007). Even as a 12-year old, Sage is held responsible for sending out sexual signals that her rapist reads as an invitation to sex. In her research into acquaintance rape, Joanna Bourke (2007:43) explains that 'commonly held notions about male sexual needs and female seductiveness, together with problems associated with amassing evidence ("she said" versus "he said")' make it 'almost impossible' for a woman to have an acquaintance rapist prosecuted successfully. Sage's response when Vicki asks her what her parents did when they heard about the rape reveals that she had internalised these social messages about women's complicity in their own sexual victimisation. She says that she never told her parents because of the following reasons: "They'd never have believed me", she continues. "They knew the guy and everything. My word against his"' (p. 340). She also chose not to tell her sister because the 'guy was practically Pete's [her brother in law] best mate'. Although they are talking about it, the word 'rape' remains unspeakable, even between the two best friends. Vicki asks 'So you must've seen him around after and stuff? You know ... after'. 'After', 'stuff', 'you know' and ellipses are as close as they can come to articulating the rape. Sage admits that having to see her attacker as part of her family's social circle 'was the worst'. Sage has been raped by a man she should have been able to trust and her sense of shame and the anticipation of social blame have rendered her silent and severely disempowered. Vicki, who has had similar experiences, makes the link with Sage's secret selfharming: "'So that's why you ... hurt yourself?" "Yeah." She [Sage] shrugs. "'Spose. Who knows?"' (p. 340). McAndrew and Warne (2005:178) contend that the infliction of self-harm is a behaviour that enables 'overwhelming emotional pain to be localized physically'. The self-harming thus becomes a mechanism though which overwhelming psychic trauma can be concretised and contained, albeit by inflicting more damage on the body of the survivor.

\section{Conclusion}

Pompidou posse offers a literary representation of the intricate negotiations that female characters perform when they attempt to deal with shame, self-blame and trauma after sexual assaults by acquaintances. In her research into trauma, Judith Herman (1992:1) notes that 'certain violations of the social contract are too terrible to utter aloud: this is the meaning of the word unspeakable' (emphasis in original). Through Vicki and Sage's experiences, Lotz reveals the complex dynamics that render rape unspeakable for these female characters. The details of the assaults themselves remain elusive because of both alcohol consumption and their traumatic nature since trauma resists clear, linear narrativisation. In addition, the characters are exposed to overwhelming social messages of female culpability. As a result, they anticipate blame to such an extent that they blame themselves and internalise this blame as shame. By focusing on the bodies of the survivors, Lotz demonstrates the embodiment of shame, but she also suggests a corporeal challenge to silencing. The bodies of these characters' speak loudly and they function to alert them to danger, to help them excavate memories that are made inaccessible and to testify to traumatic sexual assault.

\section{Acknowledgements Competing interests}

I declare that I have no financial or personal relationship(s) that may have inappropriately influenced me in writing this article.

\section{References}

Ahmed, S., 2004, The cultural politics of emotion, Edinburgh University Press, Edinburgh. Baker, K.K., 1999, 'Sex, rape and shame', Boston University Law Review 79, 663-716.

Banyard, K., 2010, The equality illusion: The truth about women and men today, Faber and Faber, London.

Bartky, S.L., 1990, Femininity and domination: Studies in the phenomenology of oppression, Routledge, New York.

Bauer, L.L.S., 2011, 'Book review: J. Brooks Bouson. Embodied shame: Uncovering disciplinary Journal 40(3), 366-368. http://dx.doi.org/10.1080/00497878.2011.5 53512

Bourke, J., 2007, Rape: A history from 1860 to the present, Virago Press, London.

Bouson, J.B., 2009, Embodied shame: Uncovering female shame in contemporary women's writings, State University of New York Press, Albany.

Cameron, C.A. \& Stritzke, W.G.K., 2003, 'Alcohol and acquaintance rape in Australia: Testing the presupposition model of attributions about responsibility and blame', Journal of Applied Social Psychology 33(5), 983-1008. http://dx.doi. org/10.1111/j.1559-1816.2003.tb01935.x

Carr, E.R. \& Szymanski, D.M., 2011, 'Sexual objectification and substance abuse in young adult women', The Counseling Psychologist 39(1), 39-66. http://dx.doi. org/10.1177/0011000010378449

Chasteen, A.L., 2001, 'Constructing rape: Feminism, change, and women's everyday understandings of sexual assault', Sociological Spectrum: Mid-South Sociological Association 21(2), 101-139. http://dx.doi.org/10.1080/02732170121403

Cowan, S., 2008, 'The trouble with drink: Intoxication, (in)capacity, and the evaporation of consent to sex', in Social Science Research Network, viewed 05 February 2013, from http://papers.ssrn.com/sol3/papers.cfm?abstract_id=1837571

Culbertson, R., 1995, 'Embodied memory, transcendence, and telling: Recounting trauma, re-establishing the self', New Literary History 26(1), 169-195. http:// dx.doi.org/10.1353/nlh.1995.0007

Estrich, S., 1992, 'Palm Beach stories', in J. Temkin (ed.), Rape and the criminal justice system, pp. 135-163, Dartmouth Publishing, Vermont.

Felson, R.B. \& Paré, P., 2005, 'The reporting of domestic violence and sexual assault by nonstrangers to the police', Journal of Marriage and Family 67, 597-610. http:// dx.doi.org/10.1111/j.1741-3737.2005.00156.x

Fuchs, T., 2004, The memory of the body, viewed 23 September 2013, from http:// www.google.com/search?hl=en\&ie=ISO-8859-1\&q=\%22the+memory+of +rhe+b ody\% $22+$

Herman, J.L., 1992, Trauma and recovery: The aftermath of violence from domestic abuse to political terror, Basic Books, London.

Irvine, J.M., 2009, 'Shame comes out of the closet', Sexuality Research \& Social Policy: Journal of NSRC 6(1), 70-79. http://dx.doi.org/10.1525/srsp.2009.6.1.70

Jolly, R., 2011, 'Witnessing embodiment', Australian Feminist Studies 26(69), $297-$ 317. http://dx.doi.org/10.1080/08164649.2011.606604

Kahn, A.S, Jackson, J., Kully, C., Badger, K. \& Halvorsen, J., 2003, 'Calling it rape: Differences in experiences of women who do or do not label their sexual assault as rape', Psychology of Women Quarterly 27, 233-242. http://dx.doi. org/10.1111/1471-6402.00103

Kilby, J., 2002, 'Redeeming memories: The politics of trauma and history', Feminist Theory 3(2), 201-210.

Lam, C. \& Roman, B., 2009, 'When granny is the wolf: Understanding and approaching college-aged female victims of acquaintance rape', Psychiatry 6(8), 18-26.

Laub, D., 1992, 'Bearing witness or the vicissitudes of listening', in S. Felman \& D. Laub (eds.), Testimony: Crises of witnessing in literature, psychoanalysis and history, pp. (eds.), Testimony: Crises of with
57-74, Routledge, London.

Lebowitz, L. \& Roth, S., 1994, 'I felt like a slut: The cultural context and women's response to being raped', Journal of Traumatic Stress 7(3), 363-390. http://dx.doi. org/10.1002/jts.2490070304

Lees, S., 2002, Carnal knowledge: Rape on trial, The Women's Press, London.

Lotz, S., 2008, Pompidou posse, Penguin Books, Johannesburg.

McAndrew, S. \& Warne, T., 2005, 'Cutting across boundaries: A case study using feminist praxis to understand the meanings of self-harm', International Journa of Mental Health Nursing 14, 172-180. http://dx.doi.org/10.1111/j.14400979.2005.00378.x

McDermott, S., 2011, 'The double wound: Shame and trauma in Joy Kogawa's Obasan', in W. Ruberg \& K. Steen (eds.), Sexed sentiments: Interdisciplinary essays on gender and emotion, pp. 141-163, Rodopi, Amsterdam. 
Nurka, C., 2012, 'Feminine shame/masculine disgrace: A literary excursion through gender and embodied emotion', Cultural Studies Review 18(3), 310-333.

Powell, A., 2008, 'Amor fati?: Gender habitus and young people's negotiation of (hetero)sexual consent', Journal of Sociology 44(2), 167-184. http://dx.doi. org/10.1177/1440783308089168

Rozee, P.D. \& Koss, M.P., 2001, 'Rape: A century of resistance', Psychology of Women Quarterly 25, 295-311. http://dx.doi.org/10.1111/1471-6402.00030

Scarry, E., 1985, The body in pain: The making and unmaking of the world, Oxford University Press, Oxford.

Shapiro, B.L. \& Schwarz, C.J., 1997, 'Date rape: Its relationship to trauma symptoms and sexual self-esteem', Journal of Interpersonal Violence 12(3), 407-419. http:// dx.doi.org/10.1177/088626097012003006
Tal, K., 1996, Worlds of hurt: Reading the literature of trauma, Cambridge University Press, Cambridge.

Van der Kolk, B.A., Hopper, J.W. \& Osterman, J.E., 2001, Exploring the nature of traumatic memory', Journal of Aggression, Maltreatment \& Trauma 4(2), 9-31. http://dx.doi.org/10.1300/J146v04n02_02

Vidal, M.E. \& Petrak, J., 2007, 'Shame and adult sexual assault: A study with a group of female survivors recruited from an east London population Sexual and Relationship Therapy 22(2), 159-171. http://dx.doi. org/10.1080/14681990600784143

Winkler, C., 1994, 'Rape trauma: Contexts of meaning', in T.J. Csordas (ed.), Embodiment and experience: The existential ground of culture and self, pp. 248268, Cambridge University Press, Cambridge. 